\title{
Effect of Integrated Nutrient Management on Yield of Maize Crop under Rain-Fed Condition in Eastern Part of Uttar Pradesh, India
}

\author{
Rajesh Ranjan Kumar*, Neeraj Kumar, Jang Bahadur Rana and Kedar Nath Rai \\ Department of Soil Science and Agricultural Chemistry Narendra Deva University of \\ Agriculture \& Technology Kumarganj, Faizabad (U.P.) 224229, India \\ *Corresponding author
}

A B S T R A C T

\begin{abstract}
\begin{tabular}{|l|}
\hline Key w or d s \\
Physico-chemical, \\
Yield attributes and \\
yield
\end{tabular}
Effect of "Integrated nutrient management in maize under rainfed condition in Eastern part of U.P." was conducted during kharif season of 2014-15 and 2015-16 Agronomy Research Farm Narendra Deva University of Agriculture \& Technology (Narendra Nagar), Kumarganj Faizabad (U.P.) The experiment was conducted in Randomized Block Design with three replications and twelve treatments. The soil of experimental field was silty loam in texture, poor in organic carbon $(0.29 \%)$, low in available nitrogen $\left(155.96 \mathrm{~kg} \mathrm{ha}^{-1}\right)$ medium in available phosphorus $\left(12.22 \mathrm{~kg} \mathrm{ha}^{-1}\right)$ and potassium $\left(314.00 \mathrm{~kg} \mathrm{ha}^{-1}\right)$ with $\mathrm{pH}$ of the soil (7.80). The results obtained during the course of investigation are being included here as under. The maximum grain yield of maize $\left(50.85,38.28 \mathrm{q} \mathrm{ha}^{-1}\right)$ was recorded with $\mathrm{T}_{12}$, which was significantly superior over all the treatments except $\mathrm{T}_{10}, \mathrm{~T}_{11}, \mathrm{~T}_{9}$. Application of $\mathrm{ZnSO}_{4} @ 25 \mathrm{~kg} \mathrm{ha}^{-1}$ or $\mathrm{FeSO}_{4} @ 10 \mathrm{~kg} \mathrm{ha}^{-1}$ or both jointly with $100 \% \mathrm{RDF}$, the grain yield of maize was increased $(10.20 \%, 9.72 \%, 17.27 \%)(7.99 \%, 7.03 \%, 19.30 \%)$, respectively over $100 \% \mathrm{RDF}$ alone during both years and $(64.88 \%, 64.16 \%, 55.29 \%$, $53.10 \%, 71.56 \%$ ) over control. Similarly, application of FYM @ $6 \mathrm{t} \mathrm{ha}^{-1}$ or $\mathrm{ZnSO}_{4} @ 25 \mathrm{~kg}$ $\mathrm{ha}^{-1}$ or $\mathrm{FeSO}_{4} @ 10 \mathrm{~kg} \mathrm{ha}^{-1}$ or all three jointly applied with $75 \% \mathrm{RDF}$, the grain yield of maize was increased by $11.63 \%, 21.81 \%, 20.64 \%, 26.34$ and $12.40 \%, 22.40 \%, 19.44 \%$ $27.00 \%$ over $100 \%$ RDF alone and $66.98 \%, 82.29 \%, 80.92 \%, 89.03 \%$ over control during both year.
\end{abstract}

\section{Introduction}

Maize (Zea mays L.) is one of the important cereal crops next to wheat and rice in the world. In India, it ranks fourth after rice, wheat and sorghum. Maize is being consumed both as food and fodder and also required by the various industries. In the world, it is grown over an area of 131 million ha with an annual production of 506 million tonnes and productivity of $3890 \mathrm{~kg} \mathrm{ha}^{-1}$. In India, it is cultivated over an area of 1.61 million ha with an annual production of 5.27 million tonnes and productivity of $3765 \mathrm{~kg} \mathrm{ha}^{-1}$ during rabi season. Maize is one of the most important cereal crops in the world. It plays an important role in agricultural economy by serving both as food for man and feed for animal including poultry birds. It is also known as "queen of cereals" because it has very high yield potential. Green cobs are roasted and consumed by people with great interest. The 
grains of special variety called the 'pop corn', are characterized by a hard corneous interior structure are converted into the 'popped' form, which is the favorite food for children in urban areas. Several food dishes including chapaties are prepared out of maize flours and grains. It is also a good food for poultry, piggery and other animals. The productivity of maize is largely dependent on its nutrient management. It is well known that maize is a heavy feeder of nutrients and because of this nature; it is a very efficient converter of solar energy into dry matter and high genetic yield potential than other cereal crops. Hence, it is called as 'miracle crop' and also as 'queen of cereals'.

Being a $\mathrm{C}_{4}$ plant, it is very efficient in converting solar energy into dry matter. Food grain production needs to be increased from the available cropped area to sustain and feed ever growing population. Rainfed agroecosystem constitutes $67 \%$ of the net cultivated area and occupy an important place in Indian agriculture (Singh et al., 2000). The area of maize crop under cultivation in India is about 8.93 million ha, whereas the average productivity of maize in India is $2.43 \mathrm{t} \mathrm{ha}^{-1}$. Mainly during kharif season which covers $80 \%$ area and left $20 \%$ in the rabi season. The Maize in India, contributes nearly $9 \%$ in the national food basket. Rainfed area contributes about $60 \%$ of food and nutritional need of the world population. Rainfed area in India contribute nearly $87 \%$ coarse cereals and pulses, $77 \%$ oil seeds, $80 \%$ horticulture, $60 \%$ cotton, $46 \%$ fine cereals, $100 \%$ major and minor forest products. Rainfed area supports $60 \%$ of livestock's, and $40 \%$ human population (Chander et al., 2011). Dryland occupy an important place in Indian agriculture. The unirrigated area when expressed as percentage total area under maize crop cultivation in India is around 78 percent. Furthermore, $77 \%$ soils of dryland are low in available $\mathrm{N}$, and the rest $23 \%$ are in medium availability, regarding to availability of $\mathrm{P}$,
$47 \%$ are low, while $51 \%$ are medium. Also $57 \%$ dryland soils are medium in available $\mathrm{K}$. The optimum harvests in drylands are not possible without adequate and balanced fertilization (Ramachandrappa and Mudalagiriyappa 2011). To sustain the soil fertility and crop productivity the role of organic manures and organic nutrients are very important.

In view the above facts the present investigation entitled "Integrated nutrient management in maize under rainfed condition in eastern part of U.P." was conducted during kharif seasons of 2014 and 2015 at Agronomy Research Farm of N.D. University of Agriculture \&Technology, Kumarganj Faizabad (U.P) with following objectives: To find out the effect of Integrated Nutrient Management on physico-chemical properties of soil. To assess the effect of Integrated Nutrient Management on growth, yield attributes and yields of maize.

\section{Materials and Methods}

The experiment was conducted during the kharif season of 2014 and 2015 at Agronomy Research Farm of Narendra Deva University of Agriculture and Technology, Narendra Nagar (Kumarganj), Faizabad (U.P.), which is located $42 \mathrm{~km}$ away from Faizabad on Faizabad- Raibarelly Road. Geographically, the experimental site falls under sub-tropical climate and is located at $26.47^{\circ} \mathrm{N}$ latitude and $82.12^{\circ} \mathrm{E}$ longitudes with an elevation of about 113 meter above mean sea level in the IndoGangetic alluvial soil belt of eastern Uttar Pradesh. Faizabad region receives a mean annual precipitation of about $1200 \mathrm{~mm}$. Maximum rainfall in this area is received from mid-June to end of September. However, occasional showers are very common in the month of January and February. The winter months are cold whereas, summer months are extremely hot, the western hot winds locally 
known as Loo starts from April and continues till the onset of monsoon in the month of May to June. The meteorological data recorded at the meteorological observatory of N.D. University of Agriculture \& Technology, Kumarganj Faizabad.

The initial soil samples were taken with the help of soil augur from the different locations of the plot at a depth of $15 \mathrm{~cm}$ prior to laying out the field trials. The samples were mixed thoroughly, air dried and processed for physical and chemical analysis.

The analyzed results of physical and chemical properties of soil and procedures adopted have been given in Table 1.

\section{Treatments details}

The treatments consisting of different levels of RDF along with manure sources of nutrients (FYM), Zinc Sulphate and Iron Sulphate were applied in maize as per treatments. The details of treatment are given as fallow $\mathrm{T}_{1}$ - Control, $\mathrm{T}_{2}-100 \%$ NPK (RDF- 80:40:30 kg NPK ha ${ }^{-1}$ alone), $\mathrm{T}_{3}-75 \%$ NPK alone, $\mathrm{T}_{4}-75 \% \mathrm{NPK}+$ Azotobactor, $\mathrm{T}_{5}-75 \%$ NPK + PSB, $\mathrm{T}_{6}-100 \%$ $\mathrm{NPK}+\mathrm{ZnSO}_{4} @ 25 \mathrm{~kg} \mathrm{ha}{ }^{-1}$ as soil application, $\mathrm{T}_{7}-100 \% \mathrm{NPK}+\mathrm{FeSO}_{4} @ 10 \mathrm{~kg}$ $\mathrm{ha}^{-1}$ as soil application, $\mathrm{T}_{8^{-}} 100 \% \mathrm{NPK}+$ $\mathrm{ZnSO}_{4} @ 25 \mathrm{~kg} \mathrm{ha}^{-1}$ as soil application + $\mathrm{FeSO}_{4} @ 10 \mathrm{~kg} \mathrm{ha}^{-1}$ as soil application, $\mathrm{T}_{9^{-}}$ $75 \%$ NPK + FYM @ 6t ha ${ }^{-1,} \mathrm{~T}_{10^{-}} 75 \%$ $\mathrm{NPK}+\mathrm{FYM} @ 6 \mathrm{ha}^{-1}+\mathrm{ZnSO}_{4} @ 25 \mathrm{~kg} \mathrm{ha}^{-1}$ as soil application, $\mathrm{T}_{11}-75 \%$ NPK+FYM @6t $\mathrm{ha}^{-1}+\mathrm{FeSO}_{4} @ 10 \mathrm{~kg} \mathrm{ha}^{-1}$ as soil application, $\mathrm{T}_{12^{-}}$75\% NPK+FYM @6t ha ${ }^{-1}+\mathrm{ZnSO}_{4} @ 25$ $\mathrm{kg} \mathrm{ha}^{-1}$ as soil application+ $\mathrm{FeSO}_{4} @ 10 \mathrm{~kg}$ $\mathrm{ha}^{-1}$ as soil application.

Note: - Recommended Dose of Fertilizer (80kg N, $40 \mathrm{~kg} \mathrm{P}_{2} \mathrm{O}_{5}$ and $30 \mathrm{~kg} \mathrm{~K}_{2} \mathrm{O} \mathrm{ha}^{-1}$ ),

N, P, K\% of FYM: $\left(0.45 \% \mathrm{~N}, 0.25 \% \mathrm{P}_{2} \mathrm{O}_{5}\right.$ and $0.45 \% \mathrm{~K}_{2} \mathrm{O}$ )

\section{Cultural operations}

\section{Preparation of field}

The experimental field was properly levelled followed by pre planting irrigation after at optimum tilth, the field was ploughed and layout was done as per programme.

\section{Application of FYM}

Organic sources of nutrient FYM was applied at the 15 days before sowing per treatments.

\section{Application of chemical fertilizers}

The recommended dose of fertilizers for maize is $80 \mathrm{~kg} \mathrm{~N}, 40 \mathrm{~kg} \mathrm{P}_{2} \mathrm{O}_{5}$ and $30 \mathrm{~kg} \mathrm{~K}_{2} \mathrm{O} \mathrm{ha}^{-1}$. Fertilizer doses were calculated per treatment and applied to each plot using urea, diammonium phosphate and murate of potash, zinc sulphate and iron sulphate. Entire dose of phosphorus and potassium and 33.33 per cent nitrogen were applied at the time of sowing. The remaining $2 / 3$ of the nitrogen was top dressed @ 33.3 per cent each knee high \& tassel, silking stage at $30^{\text {th }}$ and $45^{\text {th }}$ days after sowing in the form of urea.

\section{Seed treatment}

The seeds were treated with biofertilizer (Azotobacter) and Phosphorous Solubilizing Bacteria to use in respective treatments for sowing.

\section{Seeds and sowing}

Seeds of MM-1107 (A Hybrid maize variety of Dhanya seed company) were used in the experiment. Shallow furrows of $5 \mathrm{~cm}$ deep at $50 \mathrm{~cm}$ row apart were opened with the help of a marker and 2-3 seeds were dibbled at $20 \mathrm{~cm}$ apart in each furrow. The sowing operation was done on 14th July 2014 and $7^{\text {th }}$ July 2015. A week after emergence, seedlings were thinned to maintain two plants per hill. Final 
thinning was attended two weeks after the emergence to maintain only one healthy seedling per hill.

\section{After care}

To check the weed growth two hand weeding and inter cultivation were carried out commonly in all the treatments at 30 and 45 days after sowing.

\section{Harvesting}

Crop was harvested on 6th October, 2014 and 5th October 2015 by removing the cobs from the plants. The cobs were sun dried, threshed and grain yield per plot was recorded. After 15 days of sun drying, the dry weight of stalk per plot was recorded.

\section{Results and Discussion}

\section{Physical analysis}

\section{Bulk Density of soil}

Data on the effect of various integrated nutrient management in maize on bulk density of soil have been presented in Table 2. The lowest value of bulk density was measured with the treatments $\mathrm{T}_{12}(75 \% \mathrm{NPK}+\mathrm{FYM} @ 6 \mathrm{t}$ $\mathrm{ha}^{-1}+\mathrm{ZnSO}_{4} @ 25 \mathrm{~kg} \mathrm{ha}^{-1}$ as soil application $\mathrm{FeSO}_{4} @ 10 \mathrm{~kg} \mathrm{ha}^{-1}$ as soil application) and higher value (1.51) of bulk density was observed with $\left(\mathrm{T}_{1}\right)$ control during first year, (2014) and similarly during second year, (2015). The lowest value (1.43)of bulk density was recorded with treatment $\mathrm{T}_{12} \quad(75 \%$ $\mathrm{NPK}+\mathrm{FYM} @ 6 \mathrm{t} \mathrm{ha}^{-1}+\mathrm{ZnSO}_{4} @ 25 \mathrm{~kg} \mathrm{ha}^{-1}$ as soil application $\mathrm{FeSO}_{4} @ 10 \mathrm{~kg} \mathrm{ha}^{-1}$ as soil application) and higher value (1.50) was recorded with $T_{1}$ (control). The treatment $T_{12}$ is followed by $\mathrm{T}_{9}, \mathrm{~T}_{10}, \mathrm{~T}_{11}$, with the value (1.45, $1.45),(1.46,1.44),(1.45,1.43)$ respectively during both the years(2014 and 2015). The difference was not upto the level of significance in this regard during both years (2014 and 2015).Also the application of FYM reduced bulk density of the soil.

\section{Infiltration rate}

Data on the effect of various integrated nutrient management in maize crop on infiltration rate of soil has been presented in Table 1, and depicted in figure 1. The highest value(3.45) of infiltration rate was measured with treatment $\mathrm{T}_{12}\left(75 \% \mathrm{NPK}+\mathrm{FYM} @ 6 \mathrm{t} \mathrm{ha}{ }^{-1}\right.$ $+\mathrm{ZnSO}_{4} @ 25 \mathrm{~kg} \mathrm{ha}^{-1}$ as soil application+ $\mathrm{FeSO}_{4} @ 10 \mathrm{~kg} \mathrm{ha}^{-1}$ as soil application) and lowest value (3.34) of infiltration rate was measured with $\left(\mathrm{T}_{1}\right)$ control during first year(2014). During second year (2015) highest value (3.48) of infiltration rate was observed in $\mathrm{T}_{12}\left(75 \% \mathrm{NPK}+\mathrm{FYM} @ 6 \mathrm{ha}^{-1}+\mathrm{ZnSO}_{4} @\right.$ $25 \mathrm{~kg} \mathrm{ha}^{-1}$ as soil application $\mathrm{FeSO}_{4} @ 10 \mathrm{~kg}$ $\mathrm{ha}^{-1}$ as soil application) and lowest value (3.32) of infiltration rate was observed in $T_{1}$ (control) The treatment $\mathrm{T}_{12}$ is followed by $\mathrm{T}_{9}$, $\mathrm{T}_{10}, \mathrm{~T}_{11}$, with the value $(3.43,3.45)$, (3.44, $3.46),(3.44,3.47) \mathrm{cm} / \mathrm{hr}$ respectively during both years $(2014,2015)$. The difference was not upto the level of significance in this regard during both the years $(2014,2015)$. High infilteration rate was seen in those treatments where FYM was added as it increased the total porosity of the soil.

\section{Field capacity}

The data regarding field capacity of soil after harvest of the maize crop has been presented in Table 1 and depicted in figure 1. The maximum value (31.85) of field capacity were recorded under treatment $\mathrm{T}_{12} \quad(75 \%$ $\mathrm{NPK}+\mathrm{FYM} @ 6 \mathrm{t} \mathrm{ha}^{-1}+\mathrm{ZnSO}_{4} @ 25 \mathrm{~kg} \mathrm{ha}^{-1}$ as soil application $\mathrm{FeSO}_{4} @ 10 \mathrm{~kg} \mathrm{ha}^{-1}$ as soil application). While minimum value (31.22) recorded in treatment $T_{1}$ (control) during the first year (2014). During second year (2015), the highest value (31.71) of field capacity value was recorded with treatment $\mathrm{T}_{12}(75 \%$ 
NPK+FYM @ 6t ha ${ }^{-1}+\mathrm{ZnSO}_{4} @ 25 \mathrm{~kg} \mathrm{ha}^{-1}$ as soil application $\mathrm{FeSO}_{4} @ 10 \mathrm{~kg} \mathrm{ha}^{-1}$ as soil application). The minimum value (3.10) was recorded in $T_{1}$ (control). The treatment $T_{12}$ was followed by $T_{9}, T_{10}$ and $T_{11}$ with the value $(31.46,31.41)(31.55,31.55)$, (31.55.31.41), respectively during both the years (2014, 2015). The difference was not upto the level of significance in this regard during both years $(2014,2015)$. The increase in Field capacity in various treatments was due to addition of FYM which increased the water holding capacity of soil.

\section{Permanent wilting point}

The data regarding effect of integrated nutrient management on permanent wilting point of the soil at harvest of maize has been presented in Table 1 and depicted in figure 1. The maximum value (12.48) of permanent wilting point was found in treatment $\mathrm{T}_{12} \quad(75 \%$ NPK+FYM @6t ha ${ }^{-1}+\mathrm{ZnSO}_{4} @ 25 \mathrm{~kg} \mathrm{ha}^{-1}$ as soil application+ $\mathrm{FeSO}_{4} @ 10 \mathrm{~kg} \mathrm{ha}^{-1}$ as soil application) whereas the lowest value (11.58) was found in $\mathrm{T}_{1}$ (control) during first year (2014) and similarly during second year (2015), the higher PWP value (12.57) was found in $\mathrm{T}_{12}\left(75 \% \mathrm{NPK}+\mathrm{FYM} @ 6 \mathrm{t} \mathrm{ha}^{-1}+\right.$ $\mathrm{ZnSO}_{4} @ 25 \mathrm{~kg} \mathrm{ha}^{-1}$ as soil application $\mathrm{FeSO}_{4}$ @ $10 \mathrm{~kg} \mathrm{ha}^{-1}$ as soil application) and lowest PWP value (11.55) was recorded in $\mathrm{T}_{1}$ (Control). The treatment can be arranged in order $\mathrm{T}_{12},>\mathrm{T}_{9}>, \mathrm{T}_{10}>, \mathrm{T}_{11}$, with the value $(12.35,12.66)(12.38,12.47),(12.45,12.50)$, respectively during both the years (2014, 2015).The difference was not upto the level of significance in this regard during both the years $(2014,2015)$. The increase in PWP was due to the addition of FYM in various treatments.

Table.1 Initial physico-chemical properties of experimental field soil

\begin{tabular}{|c|c|c|c|}
\hline S. No. & Particulars & Values & Method employed \\
\hline A. & Physical properties & & \\
\hline 1. & Infiltration rate $(\mathrm{cm} / \mathrm{hr})$ & 3.10 & Ring inflitrometer \\
\hline 2. & Field capacity $(\%)$ & 31 & Gravimetric method \\
\hline 3. & Permanent wilting point (\%) & 11 & (Sunflower method) \\
\hline 4. & Bulk density $\left(\mathrm{g} / \mathrm{cm}^{3}\right)$ & 1.57 & Richard, (1960) \\
\hline B. & Mechanical analysis & & \\
\hline 1. & Sand $(\%)$ & 24.5 & Hydrometer method (Bouyoucos, 1936) \\
\hline 2. & Silt $(\%)$ & 53.2 & \\
\hline 3. & Clay $(\%)$ & 22.3 & \\
\hline 4. & Texture class & Silt loam & Triangular method \\
\hline C. & Chemical properties & & \\
\hline 1. & Soil reaction $(\mathrm{pH}) 1: 2.5$ & 7.80 & $\begin{array}{l}\text { 1:2.5 soil water suspension by using glass } \\
\text { electrode pH meter (Jackson, 1967) }\end{array}$ \\
\hline 2. & Electrical Conductivity $\left(\mathrm{dSm}^{-1}\right)$ & 0.33 & $\begin{array}{c}\text { Electrical conductivity bridge (1:2.5 soil water } \\
\text { suspension) }\end{array}$ \\
\hline 3. & Organic carbon $(\%)$ & 0.29 & $\begin{array}{l}\text { Walkley and Black method (Walkley and Black, } \\
1934 \text { ) }\end{array}$ \\
\hline 4. & Available $\mathrm{N}\left(\mathrm{kg} \mathrm{ha}^{-1}\right)$ & 155.96 & $\begin{array}{l}\text { Alkaline permanganate method (Subbiah and } \\
\text { Asija, 1956) }\end{array}$ \\
\hline 5. & Available $\mathrm{P}_{2} \mathrm{O}_{5}\left(\mathrm{~kg} \mathrm{ha}^{-1}\right)$ & 13.22 & Olsen's method (Olsen et al., 1954) \\
\hline 6. & Available $\mathrm{K}_{2} \mathrm{O}\left(\mathrm{kg} \mathrm{ha}^{-1}\right)$ & 314.00 & Flame photometer method (Jackson, 1967) \\
\hline 7. & Available S (ppm) & 7.47 & Turbidimetric method (Chesnin and Yien, 1950) \\
\hline 8. & Iron $(\mathrm{ppm})$ & 4.40 & DTPA extractant (Lindsay and Norvell, 1978.) \\
\hline 9. & Zinc (ppm) & 0.50 & DTPA extractant (Lindsay and Norvell, 1978). \\
\hline
\end{tabular}


Table.2 Effect of INM on physical properties of soil at harvest of the crop

\begin{tabular}{|c|c|c|c|c|c|c|c|c|}
\hline \multirow[t]{2}{*}{ Treatments } & \multicolumn{2}{|c|}{ B.D. (gm cm-3) } & \multicolumn{2}{|c|}{$\begin{array}{l}\text { Infil. Rate } \\
\text { (cm/hr) }\end{array}$} & \multicolumn{2}{|c|}{ F.C. $(\%)$} & \multicolumn{2}{|c|}{ PWP (\%) } \\
\hline & 2014 & 2015 & 2014 & 2015 & 2014 & 2015 & 2014 & 2015 \\
\hline $\mathrm{T}_{1}$ Control & 1.51 & 1.50 & 3.34 & 3.37 & 31.22 & 31.10 & 11.58 & 11.55 \\
\hline $\mathrm{T}_{2} \mathbf{1 0 0 \%} \mathrm{NPK}$ alone & 1.47 & 1.46 & 3.35 & 3.38 & 31.36 & 31.32 & 12.33 & 12.32 \\
\hline $\mathrm{T}_{3} 75 \% \mathrm{NPK}$ alone & 1.48 & 1.48 & 3.35 & 3.38 & 31.23 & 31.41 & 11.77 & 11.76 \\
\hline $\mathrm{T}_{4} 75 \% \mathrm{NPK}+$ Azotobactor & 1.49 & 1.49 & 3.35 & 3.38 & 31.15 & 31.30 & 11.75 & 11.74 \\
\hline $\mathrm{T}_{5} 75 \% \mathrm{NPK}+\mathrm{PSB}$ & 1.48 & 1.47 & 3.37 & 3.38 & 31.40 & 31.36 & 11.85 & 11.84 \\
\hline $\mathrm{T}_{6} 100 \% \mathrm{NPK}+\mathrm{ZnSO}_{4} @ 25 \mathrm{Kgha}^{-1}$ as soil application & 1.47 & 1.46 & 3.41 & 3.39 & 31.24 & 31.28 & 11.68 & 11.67 \\
\hline $\mathrm{T}_{7} 100 \% \mathrm{NPK}+\mathrm{FeSO}_{4} @ 10 \mathrm{Kgha}^{-1}$ as soil application & 1.48 & 1.47 & 3.42 & 3.44 & 31.40 & 31.30 & 11.66 & 12.36 \\
\hline 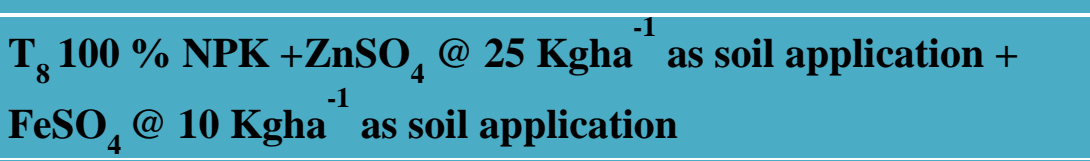 & 1.46 & 1.45 & 3.43 & 3.44 & 31.42 & 31.38 & 11.67 & 12.37 \\
\hline $\mathrm{T}_{9} 75 \% \mathrm{NPK}+\mathrm{FYM} @ 6 \mathrm{tha}^{-1}$ & 1.45 & 1.45 & 3.43 & 3.45 & 31.46 & 31.41 & 12.35 & 12.66 \\
\hline $\begin{array}{l}\mathrm{T}_{10} 75 \% \mathrm{NPK}+\mathrm{FYM} @ 6 \mathrm{tha}^{-1}+\mathrm{ZnSO}_{4} @ 25 \mathrm{Kgha}^{-1} \text { as soil } \\
\text { application }\end{array}$ & 1.46 & 1.44 & 3.44 & 3.46 & 31.55 & 31.55 & 12.38 & 12.47 \\
\hline $\begin{array}{l}\mathrm{T}_{11} 75 \% \mathrm{NPK}+\mathrm{FYM} @ 6 \mathrm{t} \mathrm{ha}^{-1}+\mathrm{FeSO}_{4} @ 10 \mathrm{Kgha}^{-1} \text { as soil } \\
\text { application }\end{array}$ & 1.45 & 1.43 & 3.44 & 3.47 & 31.55 & 31.41 & 12.45 & 12.50 \\
\hline $\begin{array}{l}\mathrm{T}_{12} 75 \% \mathrm{NPK}+\mathrm{FYM} @ 6 \mathrm{t} \mathrm{ha}^{-1}+\mathrm{ZnSO}_{4} @ 25 \mathrm{Kgha}^{-1} \text { as soil } \\
\text { application +FeSO } @ 10 \mathrm{Kgha}^{-1} \text { as soil application }\end{array}$ & 1.44 & 1.42 & 3.45 & 3.48 & 31.85 & 31.71 & 12.48 & 12.57 \\
\hline $\mathrm{SEm} \pm$ & 0.06 & 0.08 & 0.16 & 0.15 & 1.40 & 1.45 & 0.57 & 023 \\
\hline $\mathrm{CD}(\mathrm{P}=0.05)$ & NS & NS & NS & NS & NS & NS & NS & NS \\
\hline
\end{tabular}


Table.3 Effect of INM on physico-chemical properties of soil at harvest of maize

\begin{tabular}{|c|c|c|c|c|c|c|}
\hline \multirow[t]{2}{*}{ Treatments } & \multicolumn{2}{|c|}{ pH } & \multicolumn{2}{|c|}{ E.C. $\left(\mathrm{dSm}^{-1}\right)$} & \multicolumn{2}{|c|}{ O.C. $(\%)$} \\
\hline & 2014 & 2015 & 2014 & 2015 & 2014 & 2015 \\
\hline $\mathbf{T}_{1}$ Control & 7.77 & 7.76 & 0.41 & 0.40 & 0.29 & 0.30 \\
\hline $\mathrm{T}_{2} 100 \% \mathrm{NPK}$ alone & 7.75 & 7.74 & 0.39 & 0.38 & 0.30 & 0.31 \\
\hline $\mathrm{T}_{3} 75 \%$ NPK alone & 7.76 & 7.75 & 0.40 & 0.39 & 0.30 & 0.30 \\
\hline $\mathrm{T}_{4} 75 \% \mathrm{NPK}+$ Azotobactor & 7.75 & 7.75 & 0.39 & 0.38 & 0.31 & 0.31 \\
\hline $\mathrm{T}_{5} 75 \% \mathrm{NPK}+\mathrm{PSB}$ & 7.76 & 7.76 & 0.38 & 0.37 & 0.29 & 0.30 \\
\hline $\mathrm{T}_{6} 100 \% \mathrm{NPK}+\mathrm{ZnSO}_{4} @ 25 \mathrm{Kgha}^{-1}$ as soil application & 7.74 & 7.75 & 0.38 & 0.37 & 0.31 & 0.32 \\
\hline $\mathrm{T}_{7} 100 \% \mathrm{NPK}+\mathrm{FeSO}_{4} @ 10 \mathrm{Kgha}^{-1}$ as soil application & 7.75 & 7.69 & 0.37 & 0.36 & 0.30 & 0.31 \\
\hline $\begin{array}{l}\mathrm{T}_{8} 100 \% \mathrm{NPK}+\mathrm{ZnSO}_{4} @ 25 \mathrm{Kgha}^{-1} \text { as soil application+ } \mathrm{FeSO}_{4} @ 10 \mathrm{Kgha}^{-1} \text { as } \\
\text { soil application }\end{array}$ & 7.74 & 7.73 & 0.40 & 0.39 & 0.31 & 0.32 \\
\hline $\mathrm{T}_{9} 75 \% \mathrm{NPK}+\mathrm{FYM} @ 6 \mathrm{t} \mathrm{ha}^{-1}$ & 7.73 & 7.72 & 0.34 & 0.33 & 0.32 & 0.33 \\
\hline $\mathrm{T}_{10} 75 \% \mathrm{NPK}+\mathrm{FYM} @ 6 \mathrm{t} \mathrm{ha}^{-1}+\mathrm{ZnSO}_{4} @ 25 \mathrm{Kgha}^{-1}$ as soil application & 7.72 & 7.71 & 0.34 & 0.33 & 0.33 & 0.34 \\
\hline $\mathrm{T}_{11} 75 \% \mathrm{NPK}+\mathrm{FYM} @ 6 \mathrm{t} \mathrm{ha}^{-1}+\mathrm{FeSO}_{4} @ 10 \mathrm{Kgha}^{-1}$ as soil application & 7.71 & 7.70 & 0.35 & 0.34 & 0.34 & 0.35 \\
\hline $\begin{array}{l}\mathrm{T}_{12} 75 \% \mathrm{NPK}+\mathrm{FYM} @ 6 \mathrm{tha}^{-1}+\mathrm{ZnSO}_{4} @ 25 \mathrm{Kgha}^{-1} \text { as soil application + } \\
\mathrm{FeSO}_{4} @ 10 \mathrm{Kgha}^{-1} \text { as soil application }\end{array}$ & 7.70 & 7.66 & 0.33 & 0.32 & 0.35 & 0.36 \\
\hline SEm \pm & 0.33 & 0.32 & 0.04 & 0.03 & 0.01 & 0.02 \\
\hline $\mathrm{CD}(\mathrm{P}=\mathbf{0 . 0 5})$ & NS & NS & NS & NS & $\mathrm{NS}$ & 0.04 \\
\hline
\end{tabular}


Table.4 Effect of INM on yields of maize crop

\begin{tabular}{|c|c|c|c|c|}
\hline \multirow[t]{3}{*}{ Treatments } & \multicolumn{4}{|c|}{ Yields (q ha $\left.{ }^{-1}\right)$} \\
\hline & \multicolumn{2}{|c|}{ Grain } & \multicolumn{2}{|c|}{ Stalk } \\
\hline & 2014 & 2015 & 2014 & 2015 \\
\hline $\mathrm{T}_{1}$ Control & 26.90 & 20.96 & 38.10 & 32.49 \\
\hline $\mathrm{T}_{2} \mathbf{1 0 0 \%} \mathrm{NPK}$ alone & 40.24 & 30.14 & 60.10 & 45.81 \\
\hline $\mathrm{T}_{3} 75 \% \mathrm{NPK}$ alone & 35.38 & 24.26 & 52.40 & 37.50 \\
\hline $\mathrm{T}_{4} 75 \% \mathrm{NPK}+$ Azotobactor & 37.14 & 26.85 & 55.40 & 40.45 \\
\hline $\mathrm{T}_{5} 75 \% \mathrm{NPK}+\mathrm{PSB}$ & 36.20 & 25.95 & 53.90 & 38.94 \\
\hline $\mathrm{T}_{6} 100 \% \mathrm{NPK}+\mathrm{ZnSO}_{4} @ 25 \mathrm{Kgha}^{-1}$ as soil application & 44.35 & 32.55 & 66.80 & 48.40 \\
\hline $\mathrm{T}_{7} 100 \% \mathrm{NPK}+\mathrm{FeSO}_{4} @ 10 \mathrm{Kgha}^{-1}$ as soil application & 44.16 & 32.26 & 66.00 & 48.72 \\
\hline $\begin{array}{l}\mathrm{T}_{8} 100 \% \mathrm{NPK}+\mathrm{ZnSO}_{4} @ 25 \mathrm{Kgha}^{-1} \text { as soil application+FeSO } \\
10 \mathrm{Kgha}^{-1} \text { as soil application }\end{array}$ & 47.19 & 35.96 & 70.50 & 52.86 \\
\hline $\mathrm{T}_{9} 75 \% \mathrm{NPK}+\mathrm{FYM} @ 6 \mathrm{tha}^{-1}$ & 44.92 & 33.90 & 66.70 & 50.27 \\
\hline $\begin{array}{l}\mathrm{T}_{10} 75 \% \mathrm{NPK}+\mathrm{FYM} @ 6 \mathrm{t} \mathrm{ha}^{-1}+\mathrm{ZnSO}_{4} @ 25 \mathrm{Kgha}^{-1} \text { as soil } \\
\text { application }\end{array}$ & 49.02 & 36.92 & 75.00 & 54.27 \\
\hline $\begin{array}{l}\mathrm{T}_{11} 75 \% \mathrm{NPK}+\mathrm{FYM} @ 6 \mathrm{t} \mathrm{ha}^{-1}+\mathrm{FeSO}_{4} @ 10 \mathrm{Kgha}^{-1} \text { as soil } \\
\text { application }\end{array}$ & 48.67 & 36.00 & 72.95 & 53.28 \\
\hline $\begin{array}{l}\mathrm{T}_{12} 75 \% \mathrm{NPK}+\mathrm{FYM} @ 6 \mathrm{t} \mathrm{ha}^{-1}+\mathrm{ZnSO}_{4} @ 25 \mathrm{Kgha}^{-1} \text { as soil } \\
\text { application+FeSO } \\
\text { @ } 10 \mathrm{Kgha}^{-1} \text { as soil application }\end{array}$ & 50.85 & 38.28 & 75.70 & 55.98 \\
\hline $\mathrm{SEm} \pm$ & 0.85 & 0.63 & 1.30 & 0.96 \\
\hline $\mathrm{CD}(\mathrm{P}=0.05)$ & 2.50 & 1.86 & 3.82 & 2.83 \\
\hline
\end{tabular}


Fig.1
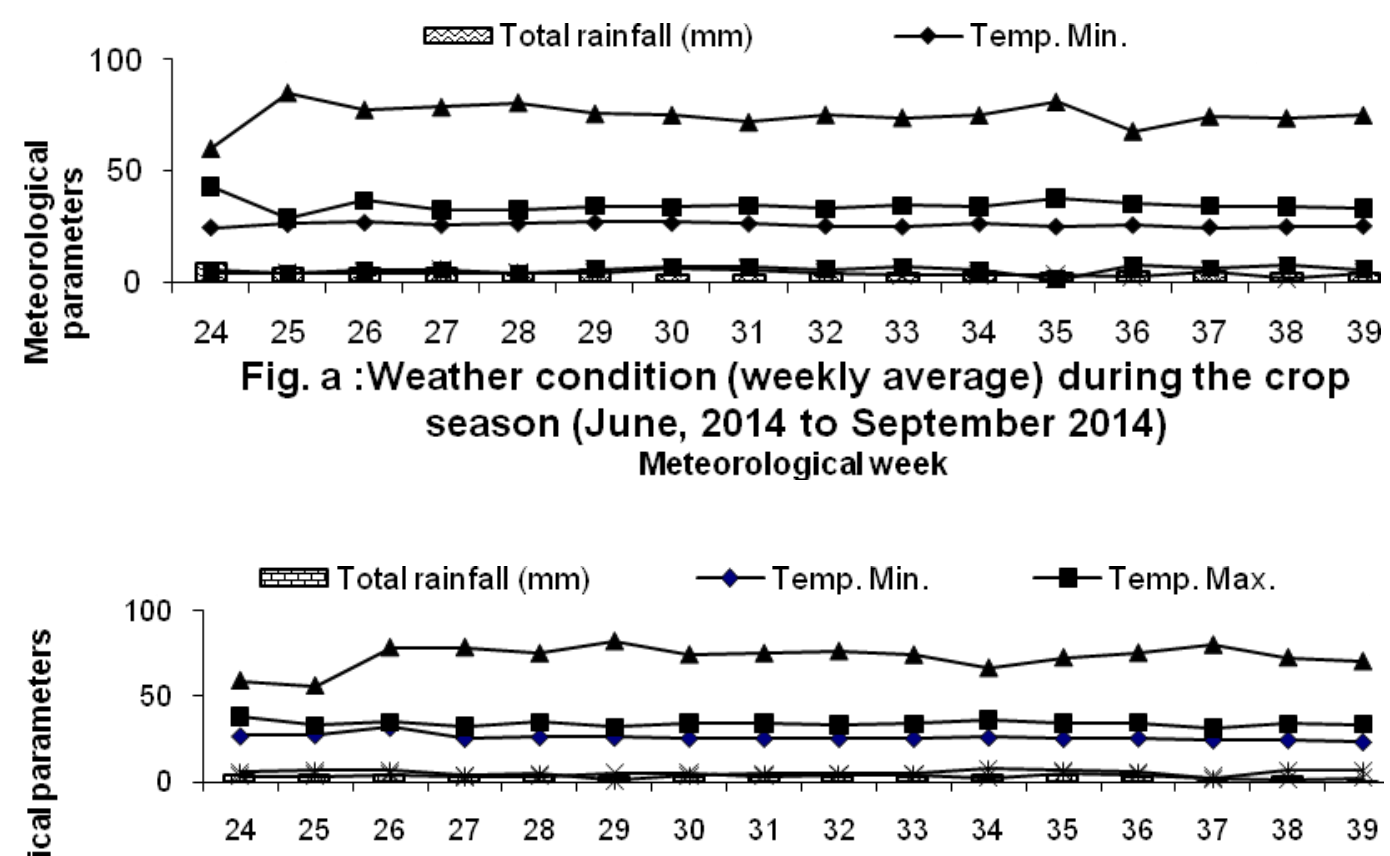

Fig. b : Weather condition (weekly average) during the crop season (June, 2015 to September 2015)

Meteorological week

\section{Chemical analysis}

\section{Soil pH}

The data regarding effect of integrated nutrient management on soil $\mathrm{pH}$ was presented in Table 3. It is clear from the table that the highest value of $\mathrm{pH}$ (7.77) was recorded in control plots and lowest value (7.70) was recorded in $\mathrm{T}_{12}(75 \% \mathrm{NPK}+\mathrm{FYM}$ @ 6t ha ${ }^{-1}+\mathrm{ZnSO}_{4} @ 25 \mathrm{~kg} \mathrm{ha}^{-1}$ as soil application+ $\mathrm{FeSO}_{4} @ 10 \mathrm{~kg} \mathrm{ha}^{-1}$ as soil application) during the first year (2014). The treatment can be arranged $\mathrm{T}_{12}>\mathrm{T}_{9}>\mathrm{T}_{10},>$ $\mathrm{T}_{11}$, with the value $(7.73,7.72)(7.72,7.71)$, $(7.71,7.70)$ respectively during both the years (2014, 2015). Similarly during the second year (2015), the highest value (7.76) of $\mathrm{pH}$ was recorded with $\mathrm{T}_{1}$ (control) while lowest value (7.66) of $\mathrm{pH}$ was recorded with $\mathrm{T}_{12}$ (75\% NPK+FYM@6t ha ${ }^{-1}+\mathrm{ZnSO}_{4} @ 25 \mathrm{~kg}$ $\mathrm{ha}^{-1}$ as soil application $\mathrm{FeSO}_{4} @ 10 \mathrm{~kg} \mathrm{ha}^{-1}$ as soil application). The reduction of $\mathrm{pH}$ was not up to the level of significance under all the treatment during both the years $(2014,2015)$. Among the treatment $\left(\mathrm{T}_{1}-\mathrm{T}_{12}\right)$ the $\mathrm{pH}$ values ranged from 7.70 to 7.77 during first year (2014) and during second (2015) year $\mathrm{pH}$ value ranged from 7.66-7.76. The major decline in $\mathrm{pH}$ was due to the addition of FYM in various treatments.

\section{$\mathrm{EC}\left(\mathrm{dSm}^{-1}\right)$}

The data regarding effect of integrated nutrient management on electrical conductivity of soil at harvest of maize have been presented in Table 3. The maximum value of electrical conductivity $\left(0.41 \mathrm{dsm}^{-1}\right)$ was recorded under the treatment $\mathrm{T}_{1}$ (control), while minimum $\left(0.33 \mathrm{dSm}^{-1}\right)$ electrical conductivity was measured under the 
treatment $\mathrm{T}_{12}\left(75 \%\right.$ NPK+FYM @ 6t ha ${ }^{-1}+$ $\mathrm{ZnSO}_{4} @ 25 \mathrm{~kg} \mathrm{ha}^{-1}$ as soil application $\mathrm{FeSO}_{4}$ @ $10 \mathrm{~kg} \mathrm{ha}^{-1}$ as soil application) during the first year(2014, 2015). Similarly during second year (2015) the maximum value (0.40) of electrical conductivity was observed in $\mathrm{T}_{1}$ (control) and minimum value (0.32) was observed in $\mathrm{T}_{12}\left(75 \% \mathrm{NPK}+\mathrm{FYM} @ 6 \mathrm{t} \mathrm{ha}^{-1}+\right.$ $\mathrm{ZnSO}_{4} @ 25 \mathrm{~kg} \mathrm{ha}^{-1}$ as soil application+ $\mathrm{FeSO}_{4} @ 10 \mathrm{~kg} \mathrm{ha}^{-1}$ as soil application). The treatments can be arranged in order of $\mathrm{T}_{12}>$ $\mathrm{T}_{9}>, \mathrm{T}_{10}>, \mathrm{T}_{11}$, with the value $(0.34,0.33)$, $(0.34,0.33),(0.35,0.34)$, respectively during both the years $(2014,2015)$ The EC of soil was not significantly affected by FYM during both the years $(2014,2015)$.The major decline in EC was due to the application of FYM in various treatments.

\section{Organic carbon $(\%)$}

The data on organic carbon content in soil at harvest of maize crop influenced by integrated nutrient management practices is presented in Table 3. Organic carbon (\%) status in soil is influenced by different nutrient supply system. Data on organic carbon shows that the slightly buildup of organic carbon was observed with all the treatments over control. Addition of FYM @ 6t/ha or $\mathrm{ZnSO}_{4} @ 25 \mathrm{~kg} / \mathrm{ha}$ or $\mathrm{FeSo}_{4} @ 10$ $\mathrm{kg} / \mathrm{ha}$ or all jointly applied with RDF the organic carbon content was increased over control. The difference was not upto the level of significance in this regard during first year (2014) while organic carbon content slightly increased in second year (2015). The highest value $(0.35)$ of organic carbon was recorded in $\mathrm{T}_{12}\left(75 \% \mathrm{NPK}+\mathrm{FYM} @ 6 \mathrm{tha}^{-1}+\mathrm{ZnSO}_{4} @\right.$ $25 \mathrm{~kg} \mathrm{ha}^{-1}$ as soil application $\mathrm{FeSO}_{4} @ 10 \mathrm{~kg}$ $\mathrm{ha}^{-1}$ as soil application) and lowest value $(0.29)$ of organic carbon was recorded in $\left(\mathrm{T}_{1}\right)$ control during first year (2014) and similarly during second year (2015), the highest value (0.36) of organic carbon was recorded in $\mathrm{T}_{12}$ (75\% NPK+FYM @ 6t ha ${ }^{-1}+\mathrm{ZnSO}_{4} @ 25$ $\mathrm{kg} \mathrm{ha}^{-1}$ as soil application $\mathrm{FeSO}_{4} @ 10 \mathrm{~kg} \mathrm{ha}^{-1}$ as soil application)) The treatment can be arranged $\mathrm{T}_{12}>\mathrm{T}_{9}>, \mathrm{T}_{10}>, \mathrm{T}_{11}$, with the value (0.32, 0.33) (0.33, 0.34), (0.34., 0.35), respectively during both the years (2014 and $2015)$ and lowest value $(0.29,0.30)$ of OC was recorded in $\mathrm{T}_{1}$ (control).

\section{Stalk yield}

A critical examination of data pertaining to stalk yield has been presented in Table 4 . The stalk yield was in the range of (38.10-75.70) $\mathrm{qha}^{-1}$ during the first year (2014). The higher value (75.70) was recorded in $\mathrm{T}_{12}(75 \%$ $\mathrm{NPK}+\mathrm{FYM} @ 6 \mathrm{t} \mathrm{ha}^{-1}+\mathrm{ZnSO}_{4} @ 25 \mathrm{~kg} \mathrm{ha}^{-1}$ as soil application+ $\mathrm{FeSO}_{4} @ 10 \mathrm{~kg} \mathrm{ha}^{-1}$ as soil application) which was significantly superior to rest of the treatment except $\mathrm{T}_{10}, \mathrm{~T}_{1}$ having value $(75.00,75.95) \mathrm{qha}^{-1}$, respectively. The lowest value (28.10) was observed in $\mathrm{T}_{1}$ (control). Application of $\mathrm{ZnSO}_{4} @ 25 \mathrm{~kg} / \mathrm{ha}$ or $\mathrm{FeSO}_{4} @ 10 \mathrm{~kg} / \mathrm{ha}$ or both with $100 \%$ RDF increased the stalk yield percentage by $(11.14 \%, 9.81 \%, 10.40 \%)$ respectively over $100 \%$ RDF alone and $(75.32 \%, 73.22 \%, 85.83 \%)$ respectively over control. Similarly the application of FYM @ 6t/ha or $\mathrm{ZnSO}_{4} @ 25 \mathrm{~kg} / \mathrm{ha}$ or $\mathrm{FeSO}_{4} @ 10$ $\mathrm{kg} / \mathrm{ha}$ or all three jointly applied with $75 \%$ RDF increased the stalk yield by $(10.98 \%$, $24.79 \%, 66.85 \%$ ) over $100 \%$ RDF alone and $(75.06 \%, 96.65 \%, 91.46 \%)$, respectively over control during first year (2014).

Also the application of Azotobactor and PSB with $75 \%$ RDF alone increased the stalk yield by $(5.72 \%, 2.86 \%)$, respectively over $75 \%$ RDF alone. Similarly during second (2015) year the stalk yield was found in the range of (32.49-55.98) qha $^{-1}$. the highest value (55.98) qha $^{-1}$ was observed in treatment $\mathrm{T}_{12}(75 \%$ NPK+FYM@6t ha ${ }^{-1}+\mathrm{ZnSO}_{4} @ 25 \mathrm{~kg} \mathrm{ha}^{-1}$ as soil application+FeSO 4 @ $10 \mathrm{~kg} \mathrm{ha}^{-1}$ as soil application) which was significantly superior to rest of the treatment except $\mathrm{T}_{10}, \mathrm{~T}_{11}$ having 
values $(54.27,53.28) \mathrm{qha}^{-1}$, respectively. The lowest value (32.49) was observed in $T_{1}$ control during the year (2015). Application of $\mathrm{ZnSO}_{4} @ 25 \mathrm{~kg} / \mathrm{ha}$ or $\mathrm{FeSO}_{4} @ 10 \mathrm{~kg} / \mathrm{ha}$ or both along with $100 \%$ RDF increased the stalk yield by $(5.65 \%, 6.35 \%, 15.38 \%)$ respectively over $100 \% \mathrm{RDF}$ alone and (48.96\%, 49.95\%, 62.69\%) over control. Similarly application of FYM @ 6t/ha or $\mathrm{ZnSO}_{4} @ 25 \mathrm{~kg} / \mathrm{ha}$ or $\mathrm{FeSO}_{4} @ 10 \mathrm{~kg} / \mathrm{ha}$ or all three jointly applied along with 75\% RDF, increase the stalk yield was by $(9.73 \%$, $18.46 \%, 16.30 \%, 22.20 \%$ ), respectively over $100 \%$ RDF alone and $(54.72 \%, 67.02 \%$, $63.98 \%, 72.29 \%$ ), respectively over control during the year (2015). Also application of Azotobator and PSB with $75 \%$ RDF increased the stalk yield by $(7.86 \%, 3.84 \%)$ over $75 \%$ RDF alone.

\section{Physico-chemical and biological properties of soil}

It is evident from the Table 1 that the lowest value of B.D $(1.44,142) \mathrm{Mg} \mathrm{m}^{-3}$ during both the year (2014 and 2015) was measured with the treatment $\left(\mathrm{T}_{12}\right) 75 \%$ NPK+FYM @ 6t ha ${ }^{-1}$ $+\mathrm{ZnSO}_{4} @ 25 \mathrm{~kg} \mathrm{ha}^{-1}$ as soil application+ $\mathrm{FeSO}_{4} @ 10 \mathrm{~kg} \mathrm{ha}^{-1}$ as soil application which was significantly superior over all the treatments. While highest bulk density (1.51, 1.50) $\mathrm{Mg} \mathrm{m}^{-3}$ was measured with the $\mathrm{T}_{1}$ (control) during both the years $(2014,2015)$. The value of bulk density was between (1.44to1.51) in 2014 and (143to150) in 2015. The difference between the treatments was non- significant. The maximum decrease in bulk density was measured with $\mathrm{T}_{12}$ in both years while maximum increase of bulk density was found with $\mathrm{T}_{1}$ (control), and increase in respectively over initial values of the parameters. The main reason of decreasing bulk density was of segregation of soil particle due to increasing organic matter as well as stability of aggregates which leads to increase the total pore space in soil. Islam et al., (2013) has also concluded the addition of organic matter through organic fertilizers, decrease bulk density of soil. It is evident from the Table 2 that the highest infiltration rate was recorded in $\mathrm{T}_{12}(75 \% \mathrm{NPK}+\mathrm{FYM} @$ $6 \mathrm{t} \mathrm{ha}{ }^{-1}+\mathrm{ZnSO}_{4} @ 25 \mathrm{~kg} \mathrm{ha}^{-1}+\mathrm{FeSO}_{4} @ 10$ $\mathrm{kg} \mathrm{ha}^{-1}$ ) with value (3.45and 31.48) during both years (2014 and 2015) and minimum value was recorded in $_{1}$ (control) with the value (3.34 and 3.37) during both the years (2014, 2015). Although there was no significant difference between the various treatment. Among the treatments treatment $\mathrm{T}_{12}$ was significantly superior over all the treatments. The infiltration rate of soil depends upon the arrangement of soil particle, porosity, stability of soil aggregates. The soil of the treatment in which biofertilizer green manuring with sunheep and compost were applied in combination recorded higher infiltration rate which might be due to better soil particle aggregation microbial respiration inter pore space and decreased bulk density. Similar result in infiltration rate as the effect of addition of organic and inorganic fertilizer in soil was reported by Martens and Frenkenberger (1992) and Rasoulzaheh and Yaghoubi (2010). It is evident from the Table 2 that the highest Field capacity during both the years $(2014,2015)$ was observed in $\mathrm{T}_{12}$ (75\% NPK+FYM @ 6t ha ${ }^{-1}+\mathrm{ZnSO}_{4} @ 25 \mathrm{~kg}$ $\mathrm{ha}^{-1}+\mathrm{FeSO}_{4} @ 10 \mathrm{~kg} \mathrm{ha}^{-1}$ ) having value 31.85 and 31.71, respectively which was significantly superior over all the treatments. The lowerst value was found in $\mathrm{T}_{1}$ control $(3.22,31.10)$ during both the years (2014 and 2015). The Table 2 shows that the application of FYM has increased the field capacity of the soil in respect to other treatment during both the years $(2014,2015)$. Intercropped green manure increase infiltration rate of soil considerably besides enhancing soil nitrogen which resulted in increased yield of maize. Sarwad et al., (2005) also reported significant reduction in bulk density and improve infiltration rate water stable aggregates, 
hydraulic conductivity maximum water holding capacity of soil with incorporation of sunheap or green manure in rabi-shorgum, chickpea sequence. In Table 2 the value of Permanent wilting point has been found highest in $\mathrm{T}_{12}\left(75 \%\right.$ NPK+FYM @ 6t ha ${ }^{-1}+$ $\mathrm{ZnSO}_{4} @ 25 \mathrm{~kg} \mathrm{ha}^{-1}$ as soil application+ $\mathrm{FeSO}_{4} @ 10 \mathrm{~kg} \mathrm{ha}^{-1}$ as soil application) $(12.48,12.57)$ during both the years (2014 and 2015) while lowest PWP was observed in the treatment $\mathrm{T}_{1}$ (control) $(11.66,11.67$ ) during both the years. As shown in the Table 2 the PWP has been decreased in the treatment where FYM incorporated along with inorganic fertilizers application of FYM because of FYM has higher water holding capacity. The PWP was increased in treatment $\mathrm{T}_{9}, \mathrm{~T}_{10}, \mathrm{~T}_{11}, \mathrm{~T}_{12}$ as compared to other treatments. Although the difference between the treatments were not to the level of significance in this regard, incorporation of farm yard manure improved soil profile, water content, PWP, root and leaf growth (Agrawal et al., 1995)also reported that. It is evident from the Table 3 that the maximum reduction of soil $\mathrm{pH}$ and EC over its initial value was recorded with the application $\left(\mathrm{T}_{12}\right)$ 75\% NPK+FYM@6t ha ${ }^{-1}+\mathrm{ZnSO}_{4} @ 25 \mathrm{~kg} \mathrm{ha}^{-1}$ as soil application $+\mathrm{FeSO}_{4} @ 10 \mathrm{~kg} \mathrm{ha}^{-1}$ as soil application. $\mathrm{pH}$ decreased over initial value under most of the treatments where FYM applied along with inorganic fertilizer. When manures and chemical fertilizers are applied to soil, the decomposition processes produce various acids which reduce the soil $\mathrm{pH}$. And during nitrification process, it releases $\mathrm{H}^{+}$in soil solution. Application of Azotobacter and phosphate solubalizing bacteria as biofertilizers are also responsible for decreasing soil $\mathrm{pH}$ with producing organic acids. Similar result were also reported reported by Mohammadi and Sohrabi (2012). Results collaborate with the choudhary et al., (2013).This attributed to the higher contribution of biomass to the soil in the form of larger root biomass, crop stubbles and residues after harvest and additive effect of FYM in accumulation of organic carbon. Singh and Sarkar (2001) also reported that the application of organic matter (FYM) decreased the soil $\mathrm{pH}$ and EC. In the present investigation of organic carbon, available nitrogen, phosphorus and potassium content were significantly influenced by integrated nutrient management practices. The percent of organic carbon has increased due to addition FYM in respective treatment.

\section{Yield and yield attributes of maize}

Nutrient management system involving organics like, FYM and chemical fertilizers $\mathrm{N}, \mathrm{P}, \mathrm{K}, \mathrm{ZnSO}_{4}$ and $\mathrm{FeSO}_{4}$ is a better way to achieve higher grain yield and maximize net returns. The growth and yield of crop plants are determined by the presence of sufficient quantities of available form of nutrients in soil for plants uptake. The growth parameter of different stage of plant height $(\mathrm{cm})$, leaf area index and dry weight at 30,60, 90 and at harvest were observed highest in $\mathrm{T}_{12}(75 \%$ $\mathrm{NPK}+\mathrm{FYM} @ 6 \mathrm{t} \mathrm{ha}^{-1}+\mathrm{ZnSO}_{4} @ 25 \mathrm{~kg} \mathrm{ha}^{-1}$ as soil application $\mathrm{FeSO}_{4} @ 10 \mathrm{~kg} \mathrm{ha}^{-1}$ as soil application) followed by $\mathrm{T}_{10}(75 \% \mathrm{NPK}+\mathrm{FYM}$ @ 6t ha ${ }^{-1}+\mathrm{ZnSO}_{4} @ 25 \mathrm{~kg} \mathrm{ha}^{-1}$ as soil application). Plant height increase in response of INM in studies conducted on maize by Verma et al., (2006) and wheat, Negm and Zahran et al., (2001) which confirmed that further increase in rate of multi-nutrients application did not show any increment which may be possibly due to the presence of antagonistic affects, negative interactions and toxicity of some nutrients to plant as a complex phenomena that occurred when nutrients were used in combination Malakouti et al., (2008) and Sujata et al., (2008) has also been reported similar results of positive effects of combination of sunhemp green manuring, use of biofertilizers and compost with inorganic fertilizers on growth and yield attributing characters of rainfed maize. No of 
Grains row $^{-1}$ was found maximum in $\left(\mathrm{T}_{12}\right)$ with value (37.69 and 31.68) during both the years $(2014,2015)$ followed by $T_{10}$ and $T_{11}$. Similarly maximum number of grains Rows $/ \mathrm{cob}^{-1}$ was found in treatment $\mathrm{T}_{12}$ has with value $(13.45,13.80)$ followed by $T_{10}$ and $T_{11}$ during both the years (2014 and 2015). The grain rows ${ }^{-1}$ emergence and development depends on environmental factors like vigor, nutrient provision in proper proportions that induce it, therefore different sources of fertilizers and their combinations create statistically significant differences in the treatments. The number of grains rowscob ${ }^{-1}$ varied to applied nutrients as these outcomes substantiate by the findings of Bakry et al., (2009) who reported that different micronutrients and their combination was testified on maize crop which proved beneficial and salubrious in enhancing all physiological and yield parameters of maize crop and also gave a good response in term of number of grains number of rows per cob. On the basis of experiment conducted by Kruczek, (2005) applying different levels of multi- component fertilizer on maize crop, it is cleared that multinutrients fertilizers have a significant affect on number of grain per cob.

The increment in number of grains per cob might be due to the presence of micronutrients fertilizers. Mahgoub et al., (2010) and Siam et al., (2008) reported that, nitrogen supplied through the inorganic sources significantly influenced plant height, dry matter, leaf area index, number of days to silking and tesseling. It was mainly due to the increase in nitrogen content in soil which was responsible for the all-round enhancement of cell division within plant. As Sanya et al., (2009) and Saleem et al., (2009) found that maximum dry weight accumulation per plant had positive effect on growth character. The leaf area index was highest in $\mathrm{T}_{12}$ followed by $\mathrm{T}_{10}$. It might be due to the fact that prolonged release of FYM increased the efficiency and favorable conditions. They increased leaf area index by supplying nutrients from FYM. It also increased photosynthetic assimilates in plant which finally pushed for increasing dry matter accumulation. The result was in conformity to the findings of Sujata et al., (2008) and Farhad et al., (2009).

The maximum grain yield of maize (50.85 and $\left.38.28 \mathrm{q} \mathrm{ha}^{-1}\right)$ was recorded with $\mathrm{T}_{12} \quad(75 \%$ NPK+FYM @6t ha ${ }^{-1}+\mathrm{ZnSO}_{4} @ 25 \mathrm{~kg} \mathrm{ha}^{-1}$ as soil application+ $\mathrm{FeSO}_{4} @ 10 \mathrm{~kg} \mathrm{ha}^{-1}$ as soil application) which was significantly superior over all the treatments except $\mathrm{T}_{10}$ and $\mathrm{T}_{11}$ having value $(49.02,39.92)$ and $(48.67,36.00)$ $\mathrm{q} \mathrm{ha}^{-1}$ respectively during both the year (2014 and 2015).

The Stalk yield was highest in $\mathrm{T}_{12}(75 \%$ $\mathrm{NPK}+\mathrm{FYM} @ 6 \mathrm{tha}^{-1}+\mathrm{ZnSO}_{4} @ 25 \mathrm{~kg} \mathrm{ha}^{-1}$ as soil application+ $\mathrm{FeSO}_{4} @ 10 \mathrm{~kg} \mathrm{ha}^{-1}$ as soil application) with value (75.70 and 55.98) and followed by $\mathrm{T}_{10}$ and $\mathrm{T}_{11}$ with value (75.00, $54.27)$ and(72.95, 53.28) during both the year (2014 and 2015).The treatment $\mathrm{T}_{12} \quad 75 \%$ NPK+FYM @ 6t ha ${ }^{-1}+\mathrm{ZnSO}_{4} @ 25 \mathrm{~kg} \mathrm{ha}^{-1}$ as soil application+ $\mathrm{FeSO}_{4} @ 10 \mathrm{~kg} \mathrm{ha}^{-1}$ as soil application)was significantly superior over all the treatments. The yield advantage observed in combination of inorganic fertilizers with application of biofertilizers, green manuring and compost might be due to the increased growth and yield attributing characters in maize.

Singh et al., (2013) has also been reported that the enhancement in maize productivity with combined application of nutrients through organic and inorganic resources. However grain yield in 2015 was lower than produced in 2014 . Variation in grain yield may be due to difference in rainfall amount and distribution pattern temperature variation during growing season during first year (2014) and second year (2015). Low moisture availability effect fertilizer use efficiency and yield components in rainfed areas. Jadoon et al., (2004), Bhatti et al., (2006), Khaliq et al., (2006) and Ahmad et al., (2008) also recorded better yield of crop by integrated use of organic and mineral fertilizer.

On the basis of results obtained in this experiment, it can be safely concluded that substitution of $25 \%$ recommended dose of 
inorganic fertilizers through FYM and use of micro nutrients $\left(\mathrm{ZnSO}_{4} @ 25 \mathrm{~kg} \mathrm{ha}^{-1}\right.$ and $\mathrm{FeSO}_{4}$ (a) $10 \mathrm{~kg} \mathrm{ha}^{-1}$ ) significantly increased the yield and yield attributes of maize over control, 75\% $\mathrm{RDF}$ and $100 \% \mathrm{RDF}$ alone supplied through inorganic fertilizers alone. Higher availability of nutrients were found with $\left(75 \% \mathrm{RDF}+\mathrm{ZnSo}_{4}+\right.$ $\mathrm{FeSo}_{4}$ ). Application of organic fertilizer like FYM was found to be better than chemical fertilizers alone in improving chemical and biological properties of soil. Addition of organic sources like FYM, increases the NPK uptake by maize crop.There was immense effect of integrated nutrient management practices on maize crop productivity and quality. These farm practices are proved to be economical in long term use. Similarly maximum net return of maize production (Rs. 36050, 33573) and maximum B: $\mathrm{C}(1.19,1.22)$ ratio were also found with $\mathrm{T}_{12}\left(75 \% \mathrm{NPK}+\mathrm{FYM} @ 6 \mathrm{t} \mathrm{ha}^{-1}+\right.$ $\mathrm{ZnSO}_{4} @ 25 \mathrm{~kg} \mathrm{ha}^{-1}$ as soil application $\mathrm{FeSO}_{4}$ @ $10 \mathrm{~kg} \mathrm{ha}^{-1}$ as soil application) during both the years (2014 and2015).

\section{References}

Chander, S.; (2011) Harvesting potential of rainfed agriculture, agriculture specialfertilizer used rainfed vs irrigated area. Vol (7) ISSN 0973-1822.

Choudhary, S.K.; Sharma, S.R. and Singh, P. (2013). Effect of organic manures and biofertilizers on soil organic carbon and productivity of groundnut in loamy sand soil. Annals of Plant and Soil Research 15: 77-78.

Gable D. B.; Kudbe K. J.; Katore J. R.; Fiske A. V and Deshmukh M. R. (2008). Physiochemical properties of soil as affected by integrated nutrient management in maize - chickpea cropping system. J. Soils and Crops, 18 (2): 462-468.

Ibragiov, A. C.; (1990). Nutrient uptake and accumulation in maize grown in sandy soils. Izvestiya-Akademii-Nauk Turkemenskoi SSR-SeriyaBiologicheskikb-Nauck, 1: 29-34.

Ramachandrappa, B. K.; and Mudalagiriyappa, (2011). Nutrient management strategies for coarse serials based production system. India Journal Fertilizer, vol.7 (4): $68-78$

Ray, S.S.; and Gupta, R.P. (2001). Effect of green manuring and tillage practices on physical properties of puddle loam soil under rice-wheat cropping system. $J$. Indian Soc. Soil. Sci., 49 (4): 670-678.

Sahoo, S.C.; and Panda, M.M. (1999). Effect of nitrogen and plant population on yield of baby corn (Zea mays). Indian Journal of Agricultural Sciences, 69(2): 157-158.

Singh, D. P.; Rana, N. S.; Singh, R. P. (2000). Growth and yield of winter maize (Zea mays) as influenced by intercrops and nitrogen application. Indian Journal of Agronomy; 45 (3): 515-519.

Singh, M.K.; Singh, R.N., Singh, S.P., Yadav, M.K. and Singh, V.K. (2010). Integrated nutrient management for higher yield, quality and profitability of baby corn (Zea mays L.). Indian Journal of Agronomy, 55(2): 100-104.

Singh, T.P.; Jha, P.B. and Akhtar, S.A. (1988). High yielding composite maize for rabi cultivation. Indian Farming, 38 (6): 7-11.

\section{How to cite this article:}

Rajesh Ranjan Kumar, Neeraj Kumar, Jang Bahadur Rana and Kedar Nath Rai. 2018. Effect of Integrated Nutrient Management on Yield of Maize Crop under Rain-Fed Condition in Eastern Part of Uttar Pradesh, India. Int.J.Curr.Microbiol.App.Sci. 7(09): 21-34.

doi: https://doi.org/10.20546/ijcmas.2018.709.004 